\title{
EVALUATION SOME NEW HYBRIDS FOR CULTIVATION IN CONVENTIONAL SYSTEM IN SPRING CLIMATIC CONDITIONS OF ROMANIA
}

\author{
DRAGHICI E.M. AND PELE M.* \\ University of Agronomical Sciences and Veterinary Medicine, Faculty of Horticulture, Bucharest, Romania \\ *Corresponding Author: Email-mpele50@yahoo.com
}

Received: November 05, 2012; Accepted: November 22, 2012

\begin{abstract}
Considering the fact that in Romania, the vast majority of tomatoes harvest comes from the farmers who have relatively small areas of solariums and greenhouses, between 100 and 2000 sqm, farmers are always looking for new hybrids with the special productive performance in low temperature conditions corresponding to beginning of spring, with resistance to diseases and pests.

Aim of this study was to test and recommend farmers from the south of Romania's new tomatoes hybrids with outstanding performance for the culture in solar of the tomatoes in conventional system (culture on soil) with early production.

In this context, it has studied 11 hybrids the Israeli provenance tomatoes.

Among hybrids analyzed, the best results in relation to the tomatoes productive potential per $1 \mathrm{~m}^{2}$ were obtained for 3319 hybrid noted V8 with a production of $16.667 \mathrm{~kg} / \mathrm{m}^{2}$ under the conditions of the early spring with a day maximum temperature of $20^{\circ} \mathrm{C}$. In addition, although this hybrid germinated least (only $87 \%$ of seeds) and later towards others tested (after 11 days) had the highest early production $9.060 \mathrm{~kg} / \mathrm{m}^{2}$ at first harvest from July 1 .

In terms of storage conditions at $9^{\circ} \mathrm{C}$, the best behavior has had the hybrid 3351 whose firmness was kept undisturbed for 2 weeks.

Such meticulous tests concerning the overall development of hybrids of germination, growth, flowering and production showed the importance of these experiments to identify the most suitable hybrids for envisaged climatic conditions and culture. In this specific, case the hybrid 3319.
\end{abstract}

Keywords- tomatoes hybrids, climatic conditions, solar, productivity

Abbreviations- IF: fruit shape index, $\mathrm{cm}$ : centimeter, $\mathrm{mm}$ : millimeter, \%: percent, g: gram, $\mathrm{kg}$ : kilogram, $\mathrm{cm}^{2}$ : square centimeter, $\mathrm{m}^{2}$ : square meter, MU: Measuring unit, DL: degrees of their liberty, Mt: control, O: significant negative, $\mathrm{N}$ : insignificant, ${ }^{*}$ : significant, ${ }^{* * *}$ : very significant

Citation: Draghici E.M. and Pele M. (2012) Evaluation Some New Hybrids for Cultivation in Conventional System in Spring Climatic Conditions of Romania. International Journal of Agriculture Sciences, ISSN: 0975-3710 \& E-ISSN: 0975-9107, Volume 4, Issue 7, pp-299-305.

Copyright: Copyright@2012 Draghici E.M. and Pele M. This is an open-access article distributed under the terms of the Creative Commons Attribution License, which permits unrestricted use, distribution and reproduction in any medium, provided the original author and source are credited.

\section{Introduction}

Tomatoes are today one of the most respected and consumed vegetables worldwide. In 2010 the area planted with tomatoes was $4,338,834$ ha and production of $145,751,507$ tons. Actually, tomatoes dominate the production of vegetables in the EU. Area planted with tomatoes Europe represented approximately $13 \%$ of the world total area and production achieved was $14 \%$ of the world [1]. In addition, the statistical data we noticed that in 2010 the area planted with tomatoes decreased by about $5 \%$ compared with 2005 , but total production was about $11 \%$ higher than the average production in 2005.The main countries tomato producers are Italy and Spain, which assume $2 / 3$ of the total production. In 2012, Romania area cultivated with vegetables accounted for about $9 \%$ of the area planted with tomatoes in Europe, and the average production was at half of the average production in European countries. Therefore the annual production of vegetables in Romania varies around 750 000 tones [2].

For example from official the statistical data published by FAO in 2012 is noted that both Israel and the Netherlands, the main countries supplying tomato hybrids for Romania, areas planted with tomatoes are very small compared to Romania. However, yields obtained on one ha are very high in Holland $479411 \mathrm{~kg} / \mathrm{ha}$ compared with Israel $85883 \mathrm{~kg} / \mathrm{ha}$ and especially in Romania of 15446 $\mathrm{kg} / \mathrm{ha}$ in 2012 [1].

The content of tomatoes in sugars, vitamins, minerals, amino acids and organic acids, which play a large role in the human body's physiological balance, determine also the therapeutic value of 
these products. Although in Europe are cultivated of only around 130 years, have come to be consumed both those reached the physiological maturity as well as green. The range of ways in which they are consumed is extremely varied: fresh in simple salads or with other vegetables, pickled, cooked in various broths, soups, processed foods and industrial pasty, broth, canned, regular or spicy juices etc. [3].

In addition to the nutrients listed, tomatoes contain a compound "miracle" for medicine, lycopene. Numerous medical studies have showed the direct action of this pigment on free radicals in the body.

Free radicals are considered particularly strong oxidative molecules that attack cell membranes of various tissues of the body, attacking also human DNA inducing replication defective processes that lead to rapid aging of the body [4].

These properties determine their wide consumption. Thus, in the world of all of the tomatoes produced annually, about $80 \%$ are sold in various forms processed and only $20 \%$ are consumed fresh.

To meet the needs of Tomatoes, the official lists of varieties of the world or the EC as well as in Romania try annually new tomato hybrids with resistance to temperature variations, diseases and pests, with a very high productivity and high capacity storage.

In Romania, the largest tomato production is obtained from small farmers who are particularly interested in newly created varieties. It is known that hybrids may respond differently in terms of production in particular to the environmental conditions. $[5,6]$. Therefore testing new hybrid tomato concerning their productivity is a priority for most researchers in order to prescribe to farmers the most appropriate hybrid both for the climate [7-11] as well as for the culture system [7].

Due to high demands of tomatoes during the entire year, they are cultivated not only in the field but also in greenhouses and solariums. Exigencies of the consumers concerning the quality of tomatoes have known a strong orientation towards the sensory seeking and appreciating as much as taste and flavor tomatoes even at the expense of a commercial aspect of the fruit perfectly. The biological material choice for tomato cultures setting up is an important sequence of vegetable culture technology under shelter [12-15]. Most of the extra early hybrids introduced in Romania over time were hybrids of Dutch origin.

From officially the statistical data published by FAO in 2012 is noted that in the Netherlands yields obtained on one ha are very high compared with those in Romania [1]. Not all hybrids that are marketed for cultivation in greenhouses and solariums shows adaptability and resistance to all pathogens that attack tomato plants or climate variations in Romania. This may be one of the causes of differences in production per hectare between the two countries. Tomato growers trying to overcome these disadvantages by choosing the hybrids suitable for their culture system offered on the market.

In examining of different varieties are taken into consideration a minimum of characters that tomatoes must cover according to the protocol of Community Plant Variety Office (CPVO)-TP 44/3 of 21.03.2007 [16], namely concerning the seedlings, stem, plant, flowering, during flowering and fruit maturation period.

In this context, it is necessary that tomato market of Romania to be enriched with hybrids adapted to the conditions in this country. Varieties that besides a high yield to be developed conveniently and in the conditions enabling energy savings through early development even at lower temperatures.

Thus in this paper are analyzed several hybrids of Israel with marketing perspective. These hybrids are supposed to have increased resistance to specific environmental conditions during the Romanian spring (low temperature specific first part of spring, days shorter, high nebulosity, high relative humidity), to pests and diseases but which on the other hand ensures high yields and high quality of early tomatoes respectively their appearance, taste and a long shelf life. In addition the introduction of new hybrids in production is envisaged and diversification of early tomatoes. It also takes into consideration the need to assess the various hybrids under protected culture in order to develop recommendations on their suitability for cultivation in solariums.

\section{Material and Methods}

The experiments were placed in the teaching and experimental field, namely in the unheated solarium of the Department of Vegetable Growing. The experiments were conducted during February to August 2011.

In experiments were used 11 hybrids of Israeli origin: V1-3349; V23350; V3-3330; V4-3326; V5-3323; V6-3335; V7-3351; V8-3319; V9-3352; V10-3348; and V11-2821.

Sowing was carried out in greenhouse multiplier, providing a constant optimum temperature for germination of $20^{\circ} \mathrm{C}$. For sowing and transplant we used professional substrate Plantaflor stamp to produce seedlings purchased from the Hortigala company, Germany, with the following composition: $30 \%$ red peat and $70 \%$ black peat with $0-7 \mathrm{~mm}$ granulation and $\mathrm{pH}\left(\mathrm{H}_{2} \mathrm{O}\right)$ of 5.5-6.0. The level of fertilization was of $0.8 \mathrm{~kg} / \mathrm{m}^{3}$.

Culture was established in the solarium, on 04.04.2011. Planting scheme was as follows: the distance between rows $70 \mathrm{~cm}$ and $40 \mathrm{~cm}$ between plants in the row. Culture was mulched with biodegradable foil. Plant density was 3.5714 plants $/ \mathrm{m}^{2}$ respectively 35,714 plants per one ha.

The care works seedlings were applied: daily watering, thinning plants when they grew; 2 treatments with Mospilan $0.2 \%$ for greenhouse whiteflies; two preventive treatments with Merpan $0.2 \%$ when seedlings had 4 true leaves and 2 days before planting with Topsin $0.2 \%$. The care works cultures were applied. Dripping watering plants whenever it was necessary. Plants were trellising after about 12-14 days after planting. The management and guiding plant growth around the string; pinch off the shoots as they arose when they were about $5-10 \mathrm{~cm}$. Growth limited in height after 5-7 inflorescences. Basal leaves defoliation. Phytosanitary treatment with Topsin $0.2 \%, 0.2 \%$ Merpan and 4 treatments for greenhouse whiteflies and spider with Mospilan $0.2 \%$ and Nisorun.

The following analysis and determinations were made:

At the seedlings: dynamics of seed germination, dynamic growth in height of tomato seedlings, dynamics of the number of leaves. 
In culture: dynamic growth in the solarium of plants height, the dynamics of the inflorescences, the number of leaves per plant, the number of inflorescences, the number of flowers and fruits in the inflorescence, the average weight of fruits, the early and total production, fruits characteristics concerning average weight, shape index, fruits colour and the characteristics concerning the fruits keeping of under controlled conditions.

The measurements concerning of plants height growth were made at an interval of 10 days. The number 0 leaves appeared were regularly recorded.

Harvested tomato fruits have been counted, weighed individually on inflorescences and was determined fruit shape index (fruit shape index = IF).

Statistical calculations were performed to highlight differences between experimental variants.

\section{Results and Discussion}

Among the 11 hybrids tested differences have appeared even from the germination. Thus, hybrids V3, V6 and V7 have sprung up fastest namely 4 days after sowing. Variants V1, V2, V5, V9, V10 and V11 have sprung up to 5 days, but two hybrids were germinated after 9 days (V4) respectively 11 days (V8). It can be noticed also that not all seeds germinate. The highest percentage of germination is $97 \%$ at the variant V5. V4 and V8 variants have sprung up at the latest and the germination percentages were also the lowest of $92 \%$ and $87 \%$ [Fig- 1$]$.

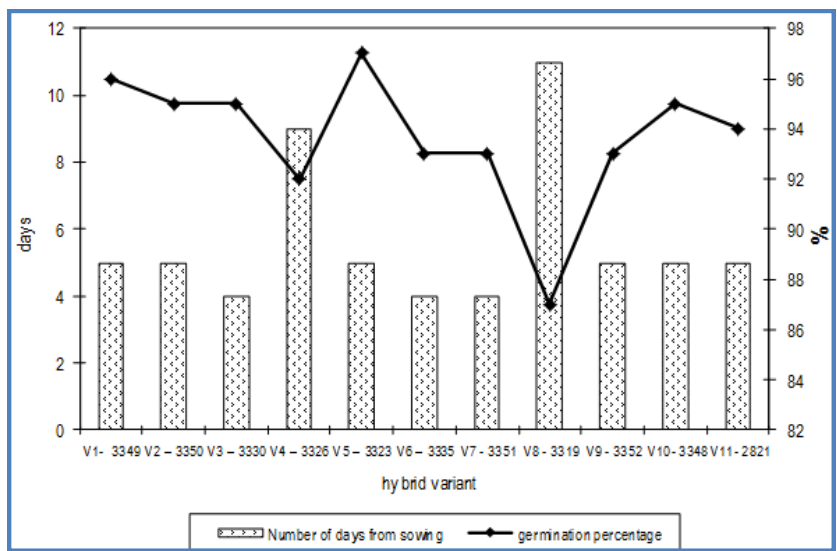

Fig. 1- Number of days from sowing to sprouting and the percentage of seeds sprung

The data presented in [Table-1] noted that seedling height determined on 25. 03. 2011 ranged from $6.33 \mathrm{~cm}$ to $12.33 \mathrm{~cm}$ for $V 8$ respectively for V11. It seedling height was expected to be the smallest for V8 considering that this variant has sprouted at the latest. Nevertheless, it is interesting however, that the variant V11, which has sprouted at five days, has a height greater than the variants that arose after 4 days. This shows a higher growth capacity of this hybrid.

From statistical point of view, the differences concerning the height between the seedlings at planting in solar were insignificant.

Another factor chased it was to determine the number of leaves in seedlings. The average results are shown in [Fig-2]. Can be noticed that in general the number of leaves of seedlings was about
5. Variant $\mathrm{V} 1$ is distinguished with an average number of leaves 7 and variant V11 with an average number of 6 leaves. The lowest number of leaves had the variant $V 8$ with an average of 4.33 leaves.

Table 1- Dynamic of growth in height of tomato seedlings

\begin{tabular}{|c|c|c|c|c|c|c|c|}
\hline \multirow[t]{2}{*}{ Variants } & \multirow[t]{2}{*}{$\begin{array}{l}\text { Measur- } \\
\text { ing unit } \\
\text { (MU) }\end{array}$} & \multicolumn{2}{|c|}{$\begin{array}{l}\text { Determination of } \\
\text { the Height of } \\
\text { Seedlings at: }\end{array}$} & \multicolumn{2}{|c|}{$\begin{array}{c}\text { The } \\
\text { difference }\end{array}$} & \multirow{2}{*}{$\begin{array}{l}\text { The } \\
\text { Signifi- } \\
\text { cance }\end{array}$} & \multirow{2}{*}{$\begin{array}{c}\text { The daily } \\
\text { average of } \\
\text { growth rate } \\
\mathrm{cm} / \mathrm{day}\end{array}$} \\
\hline & & $\begin{array}{c}\text { March } 25 \\
2011\end{array}$ & $\begin{array}{c}\text { April } 04 \\
2011\end{array}$ & $\mathrm{~cm}$ & $\%$ & & \\
\hline V1-3349 & $\mathrm{cm}$ & 9.5 & 14.25 & -0.52 & 96.5 & $\mathrm{~N}$ & 0.317 \\
\hline V2-3350 & $\mathrm{cm}$ & 10.33 & 14.33 & -0.44 & 97.04 & $\mathrm{~N}$ & 18 \\
\hline V3-3330 & $\mathrm{cm}$ & 10.67 & 15.67 & 0.9 & 106.12 & $\mathrm{~N}$ & .348 \\
\hline V4-3326 & $\mathrm{cm}$ & 7.67 & 12.67 & -2.1 & 85.8 & $\mathrm{~N}$ & 295 \\
\hline & $\mathrm{cm}$ & 8 & 16 & 1.23 & 108.35 & $\mathrm{~N}$ & 356 \\
\hline V6-3335 & $\mathrm{cm}$ & 10 & & 0.23 & 101.58 & iv & 0.333 \\
\hline V7-3351 & $\mathrm{cm}$ & 10 & 14.85 & 0.08 & 100.57 & $\mathrm{~N}$ & 0.33 \\
\hline V8-3319 & $\mathrm{cm}$ & 6.33 & 12.33 & -2.44 & 83.5 & $\mathrm{~N}$ & 0.308 \\
\hline V9-3352 & $\mathrm{cm}$ & 10.33 & 15.33 & 0.56 & 103.82 & $\mathrm{~N}$ & 0.341 \\
\hline 3348 & $\mathrm{~cm}$ & 11.67 & 15.67 & 0.9 & 106.12 & $\mathrm{~N}$ & 0.348 \\
\hline V11- 2821 & $\mathrm{~cm}$ & 12.33 & 16.33 & 1.56 & 110.59 & $\mathrm{~N}$ & 0.363 \\
\hline The average & & 9.71 & 14.77 & 0 & 100 & Control & \\
\hline
\end{tabular}

$D L=$ degrees of their liberty

DL5\%= $2.740 \quad$ DL5\% in \%= 18.5557

DL1\%= $3.900 \quad D L 1 \%$ in $\%=26.4114$

DL01\%= 5.640 DL01\% in \%= 38.1949

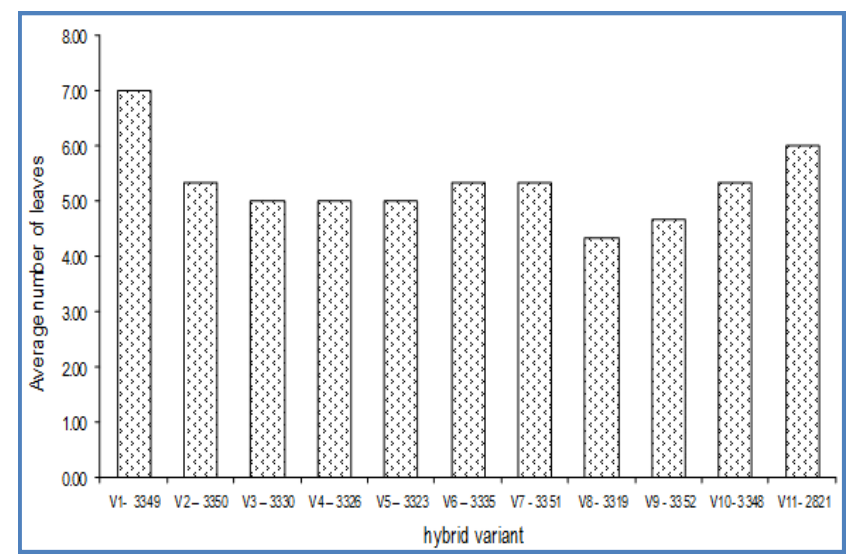

Fig. 2- Average number of leaves per hybrid at planting

According to UPOV characteristics, an important criterion for differentiating of cultivars is also the anthocyanin coloration of the plantlets hypocotyl in the seedling stage. At V1, V2, V9, V10 and V11 variants were noticed a purple colour of hypocotyls and for the rest of variants was green coloration. Dynamics of growth in height of tomato plants after planting was observed in the solar measuring the height of thereof at intervals of 10 days. Thus, the evaluation of plant growth dynamics of tomatoes in solar of the hybrids tested is represented in [Fig-3]. As it is observed, the increase rate was more than $2.2 \mathrm{~cm}$ (centimeter) per day to all hybrids. Have increased the fastest variants V1 followed by V2 and V6. The variants with belated germination have had the smallest growth rate namely V8 the smallest with $2.21 \mathrm{~cm} /$ day and V4 with $2.29 \mathrm{~cm} /$ day.

A heeded character to knowing the hybrids recommended for high tunnel and greenhouse cultures is also leaf length and size of leaflets. Between hybrids analyzed variants 3, 4, 7 and 11 presented 
rich foliage with the length of leaves between $37 \mathrm{~cm}$ and $45 \mathrm{~cm}$. This is important for determining distances of planting and carrying out of some works to remove some leaves with the aim for better circulation of the air among plants but also for better lighting the basal part.

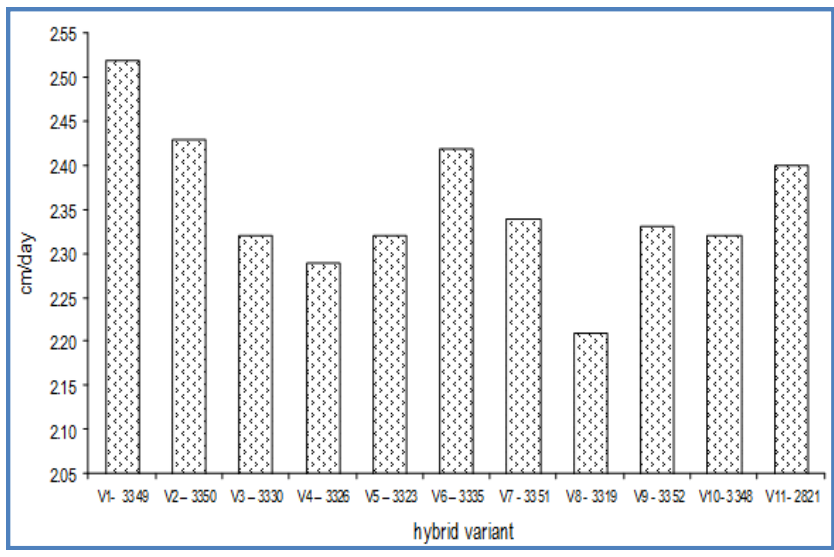

Fig. 3- Average daily rate of growth of different hybrids in $\mathrm{cm} /$ day

From the point of view of tomato growers, the most important factors are obviously the number and amount of fruit formed by each hybrid. In this context was observed the evolution of inflorescences formation, distance between them and fruits formation.

To the hybrids analyzed, it was observed that the number of inflorescences varied between 4 to 7 with a number of flowers per plant formed between 22 and 52 . Thus, the variant 7 had four blossoms and a total of 22 flowers while at variant 1 have formed a number of 7 inflorescences with a total of 52 flowers per plant. Most of the flowers were formed at variant 2, namely 53 [Table-2].

Table 2- Total number of flowers formed in inflorescences and on the plant

\begin{tabular}{lcccccccc} 
Variants & \multicolumn{9}{c}{ Inflorescences } & \multicolumn{2}{c}{ Total number of } \\
& I & II & II & IV & V & VI & VII & flowers/plant formed \\
V1-3349 & 6 & 9 & 9 & 7 & 7 & 7 & 7 & 52 \\
V2-3350 & 11 & 9 & 6 & 9 & 9 & 9 & 53 \\
V3-3330 & 7 & 8 & 6 & 8 & 8 & & 37 \\
V4-3326 & 9 & 9 & 9 & 9 & 5 & & 41 \\
V5-3323 & 7 & 7 & 7 & 9 & 7 & 5 & 42 \\
V6-3335 & 7 & 7 & 7 & 6 & 7 & & 34 \\
V7-3351 & 6 & 6 & 4 & 6 & & & 22 \\
V8-3319 & 7 & 7 & 7 & 7 & 6 & 3 & 37 \\
V9-3352 & 6 & 6 & 6 & 6 & 6 & & 30 \\
V10-3348 & 5 & 6 & 6 & 4 & 5 & & 26 \\
V11-2821 & 9 & 6 & 6 & 6 & 6 & 6 & 39 \\
\hline
\end{tabular}

Determining the average distance between inflorescences is important to assess the productive capacity of the hybrid. Distance between inflorescences was different from one hybrid to another, in average it was $19.36 \mathrm{~cm}$ per variants. Shorter distances between inflorescences were recorded at variants $1(17 \mathrm{~cm}), 8(17 \mathrm{~cm})$ and $11(17.5 \mathrm{~cm})$. The greatest distance between inflorescences, $24.5 \mathrm{~cm}$ was recorded at the variant 7 [Table-3].

From the Statistical point of view the variant 7 has made a very significant difference compared to the average of variants. Differences significant negative were at the variants $1 \& 8$. Variant 6 also showed a significant positive difference. The others hybrids did not show significant differences towards average of experiences.
Table 3- The average distance between inflorescences (at inflorescences 1-4)

\begin{tabular}{lcccc} 
Variants & $\begin{array}{c}\text { Distance between } \\
\text { inflorescences }\end{array}$ & \multicolumn{2}{c}{ Difference } & Significance \\
V1-3349 & $\mathrm{cm}$ & $\mathrm{cm}$ & $\%$ & \\
V2-3350 & 17 & -2.36 & 87.79 & $\mathrm{O}$ \\
V3-3330 & 18 & -1.36 & 92.96 & $\mathrm{~N}$ \\
V4-3326 & 20 & 0.64 & 103.29 & $\mathrm{~N}$ \\
V5-3323 & 19 & -0.36 & 98.12 & $\mathrm{~N}$ \\
V6-3335 & 17,5 & -1.86 & 90.38 & $\mathrm{~N}$ \\
V7-3351 & 22 & 2.64 & 113.62 & $*$ \\
V8-3319 & 24,5 & 5.14 & 126.53 & $* * *$ \\
V9-3352 & 17 & -2.36 & 87.79 & $\mathrm{O}$ \\
V10-3348 & 21,5 & 2.14 & 111.03 & $\mathrm{~N}$ \\
V11-2821 & 19 & -0.36 & 98.12 & $\mathrm{~N}$ \\
Average & 17,5 & -1.86 & 90.38 & $\mathrm{~N}$ \\
\hline
\end{tabular}

$D L 5 \%=2.230, D L 1 \%=3.170, D L 01 \%=4.590,0=$ significant negative, $N=$ insignificant, ${ }^{*}=$ significant, ${ }^{* * *}=$ very significant, $M t=$ control.

To all the hybrids analyzed, the inflorescences were simple, unbranched. One aspect observed only at one hybrid (V10-3348) it was issuance in large numbers of adventitious roots overall stalk.

Number of fruits produced in inflorescences and per total plant was between 17 fruits at V7 and 41 to V2. This data and the percentual assessment of fruits produced per inflorescence, per floors and per total plant are presented in [Table-4].

The lowest number of fruits per inflorescence it was seen at V7 namely an average of 4.25 fruits and the highest number at $\mathrm{V} 2$ of 6.83 fruits.

An interesting behavior had variant 1 . Thus, we can notice that the overall percentage of fruits produced per plant, was the lowest at this variant of only $61.54 \%$. However, this hybrid almost had the highest average flowers, formed per plant. It can be noticed that the lowest percentage of binding in accordance with the period when have been developed the inflorescences it was for one inflorescence I of only of only $33.33 \%$ and $28.57 \%$ for inflorescence VII. Therefore, it was the first and last inflorescence. Thus can be assumed that in this case extreme temperatures or lower or very high sunstroke would cause the low percentage of binding.

The best percentage of binding per plant was observed at the variant 8 (no. 3319) of $91.89 \%$. It likewise remarks at this hybrid, which in general on inflorescences percentage was maximum at inflorescences 1, 2, 5 and 6. In addition, this percentage was high and the other inflorescences. Thus to inflorescence 3 was $85.71 \%$ and $71.43 \%$ in inflorescence 4 [Table-4].

Fruits evaluation was performed depending on their number and the weight of each fruit.

Fruits with small masses between 30-68 g were obtained only for three hybrids namely 33 to the variant V4, 11 to the variant V2 and 2 to the variant $V 6$. Fruits with higher average weights between $141 \mathrm{~g}-170 \mathrm{~g}$ were in number of 5 to V1, V3 and V8, Of 10 respectively 24 fruits to variants 6 and 9 .

The average weight of fruits was generally different from one inflorescence to another. Thus in the [Table-5] are presented the average values of tomatoes weights per inflorescence for each hybrid. 
Table 4- The average number and the percent of fruits produced per inflorescence and plant

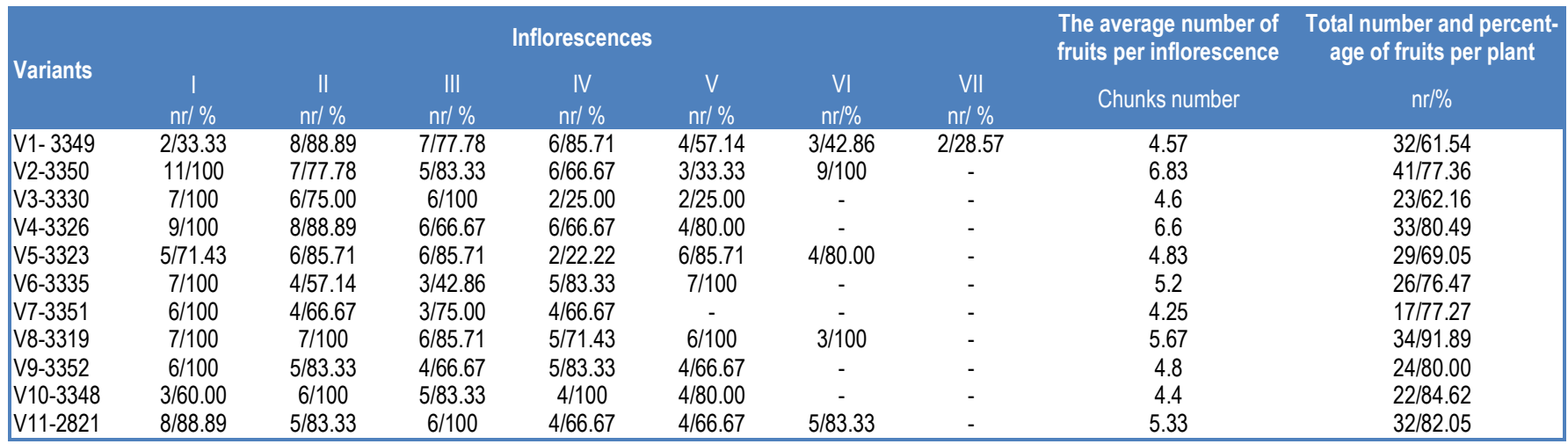

In [Table-6] are presented total masses on inflorescences and on plant harvested.

Table 5- The average weight of fruits per inflorescence $(g)$

\begin{tabular}{|lccccccc} 
Variants & \multicolumn{7}{c}{ Inflorescence } \\
& I & II & III & IV & V & VI & VII \\
V1-3349 & 122.5 & 82.78 & 103.43 & 122.33 & 124 & 157.33 & 162.5 \\
V2-3350 & 49.66 & 93.86 & 108.2 & 104.5 & 117.66 & 82.66 & \\
V3-3330 & 90.37 & 99.33 & 103.33 & 140.5 & 143.5 & & \\
V4-3326 & 48.44 & 51.38 & 55 & 53.67 & 56.25 & & \\
V5-3323 & 121.8 & 103 & 103.71 & 133.5 & 103.14 & 124.5 & \\
V6-3335 & 98.71 & 121.25 & 123.67 & 120.4 & 83.71 & & \\
V7-3351 & 113.17 & 148 & 171.66 & 156.25 & & & \\
V8-3319 & 134.86 & 136.43 & 137.33 & 140 & 135.33 & 144 & \\
V9-3352 & 153.67 & 153.4 & 173.75 & 159.4 & 187 & & \\
V10-3348 & 121.67 & 115.67 & 120.4 & 122.5 & 119 & & \\
V11-2821 & 81.88 & 94.6 & 95.67 & 96 & 95 & 95.2 & \\
\hline
\end{tabular}

Table 6- Total mass of fruits produced on inflorescences and on total plant

\begin{tabular}{|c|c|c|c|c|c|c|c|c|}
\hline \multirow{2}{*}{ Variants } & \multicolumn{7}{|c|}{ Total harvested per inflorescence, $\mathbf{g}$} & \multirow{2}{*}{$\begin{array}{l}\text { Total harvested } \\
\text { per plant in } \mathrm{g}\end{array}$} \\
\hline & I & $\|$ & II & IV & V & VI & VII & \\
\hline V1-3349 & 245 & 737 & 724 & 734 & 496 & 472 & 325 & 3733 \\
\hline V2-3350 & 585 & 664 & 546 & 633 & 356 & 753 & & 3537 \\
\hline V3-3330 & 716 & 596 & 620 & 286 & 292 & & & 2510 \\
\hline V4-3326 & 44.5 & 51.38 & 55 & 53.66 & 56.25 & & & 1724 \\
\hline V5-3323 & 609 & 715 & 720 & 267 & 716 & 498 & & 3525 \\
\hline V6-3335 & 691 & 485 & 371 & 602 & 586 & & & 2735 \\
\hline V7-3351 & 679 & 592 & 515 & 625 & & & & 2411 \\
\hline V8-3319 & 944 & 955 & 824 & 700 & 812 & 432 & & 4667 \\
\hline V9-3352 & 922 & 767 & 695 & 797 & 748 & & & 3929 \\
\hline V10-3348 & 365 & 694 & 602 & 490 & 476 & & & 2627 \\
\hline V11-2821 & 655 & 473 & 574 & 384 & 380 & 476 & & 2942 \\
\hline
\end{tabular}

At V1, the lowest fruits with an average of $82.78 \mathrm{~g}$ were obtained the second inflorescence. Within these inflorescences were obtained fruits even of 55-69 g. From inflorescences 1, 3, 4 and 5 were harvested fruits over $100 \mathrm{~g}$. From inflorescences, 6 and 7 fruits were fewer on inflorescence but the average weight of over $157 \mathrm{~g}$. The average weight of fruits harvested per plant was of $3733 \mathrm{~g}$.

From V2 were obtained smallest fruits in inflorescence 1. Within that inflorescence were formed 11 fruits. Also at inflorescences, 2 and 6 fruits were below $100 \mathrm{~g}$. The fruits from inflorescences 3,4 and 5 had a little over $100 \mathrm{~g}$. This variant has formed the most irregular fruits. Per plant were harvested on average $3537 \mathrm{~g}$ tomatoes.
The fruits harvested from the variant 3 were on average around $100 \mathrm{~g}$. The inflorescences 4 and 5 were formed only 2 each fruits and their average weight was about $140 \mathrm{~g}$. Per plant were harvested on average $2510 \mathrm{~g}$ tomatoes.

From variant 4 were harvested fruits between $48.44 \mathrm{~g}$ average mass from inflorescence 1 and $56.25 \mathrm{~g}$ from inflorescence 5 . Fruits generally small but uniforms characterize this hybrid. Total average weight per plant was harvested $1724 \mathrm{~g}$.

From the variant 5 were obtained fruits with average weight over $100 \mathrm{~g}$. Of over $120 \mathrm{~g}$ fruits were harvested from inflorescences 1,4 and 6 . At the $4^{\text {th }}$ inflorescence were obtained of over $130 \mathrm{~g}$ fruits but were only two fruits. In total $3525 \mathrm{~g}$ were harvested tomatoes on the plant.

The fruits harvested from V6 were below $100 \mathrm{~g}$ in the case of inflorescences 1 and 5 but were produced a large number of fruits per inflorescence. In this situation could have been limit the number of fruits per inflorescence so that the fruit to grow in weight. Otherwise, fruits were uniform, with average weights about $120 \mathrm{~g}$. This variant gave an average of $2735 \mathrm{~g}$ per plant tomatoes.

Large fruits characterize the variant 7 . Inflorescence 1 presented fruits with average weight of about $113 \mathrm{~g}$. The rest of the inflorescences had fruits were over $140 \mathrm{~g}$, and to inflorescence 3 the fruits were over $170 \mathrm{~g}$. The total mass of fruits harvested per plant was $2411 \mathrm{~g}$.

At the variant V8 were harvested fruits averaging about $135 \mathrm{~g}$ each. Their size was generally uniform for all inflorescences. From this variant was harvested largest amount fruit on plant, namely $4667 \mathrm{~g}$.

In the case of variant 9 the fruits had higher weights over $153 \mathrm{~g}$. At this variant was observed that the inflorescences were broken under the weight of fruits. This variant gave $3929 \mathrm{~g}$ fruits per plant.

At the variant $\mathrm{V} 10$ were obtained generally uniform fruits over about $115 \mathrm{~g}$. Most fruits have had about $120 \mathrm{~g}$. From the inflorescences were harvested from $365 \mathrm{~g}$ to inflorescence 1, from $694 \mathrm{~g}$ to inflorescence 2. A total of $2627 \mathrm{~g}$ per plant were harvested.

Small Fruits, averaging about $80 \mathrm{~g}$ to about $96 \mathrm{~g}$ were collected from V11. Fruits were generally uniform within inflorescences. The large number of fruits in inflorescences determined to obtain on inflorescence between $380 \mathrm{~g}$ and $655 \mathrm{~g}$ and $2942 \mathrm{~g}$ per plant. 
There have been a number of 4 harvests. To variants $4,5,10$ and 11 there has been no harvesting on 1 July 2011 as result these hybrids are later.

The data obtained concerning plant production are recorded in [Table-7].

Table 7- The graph of tomatoes harvest and average production obtained per plant

\begin{tabular}{|cccccc|} 
Variants & $\begin{array}{c}\text { Total } \\
\text { production } \\
\text { g/plant }\end{array}$ & $\begin{array}{c}\text { 1st harvest } \\
\text { Jul-01 } \\
\text { g/plant }\end{array}$ & $\begin{array}{c}\text { 2nd harvest } \\
\text { Jul-15 } \\
\text { g/plant }\end{array}$ & $\begin{array}{c}\text { 3rd harvest } \\
\text { Jul-23 } \\
\text { g/plant }\end{array}$ & $\begin{array}{c}\text { 4th harvest } \\
\text { Aug-01 } \\
\text { g/plant }\end{array}$ \\
\hline V1-3349 & 3733 & 779 & 865 & 1150 & 939 \\
V2-3350 & 3537 & 1120 & 780 & 975 & 662 \\
V3-3330 & 2510 & 784 & 577 & 380 & 769 \\
V4-3326 & 1724 & 0 & 830 & 450 & 444 \\
V5-3323 & 3525 & & 1650 & 985 & 890 \\
V6-3335 & 2735 & 1463 & 530 & 375 & 367 \\
V7-3351 & 2411 & 709 & 1320 & 382 & 0 \\
V8-3319 & 4667 & 2537 & 650 & 875 & 605 \\
V9-3352 & 3929 & 1695 & 1275 & 630 & 329 \\
V10-3348 & 2627 & & 1157 & 878 & 592 \\
V11-2821 & 2942 & & 1415 & 875 & 652 \\
\hline
\end{tabular}

Analyzing hybrids in terms of the early production was found that the highest percentage of $54.36 \%$ of total production was registered at hybrid V8. The data recorded can appreciate the production capacity of hybrids analyzed per $\mathrm{m}^{2}$. These assessments are presented in [Fig-4]. It can notice that in this case too hybrid V8 recorded the highest yield at $1 \mathrm{~m}^{2}$ in a period of only three months of vegetation. The hybrid V4 showed the lowest production, of only $6.1 \mathrm{~kg} / \mathrm{m}^{2}$ but also the most belated.

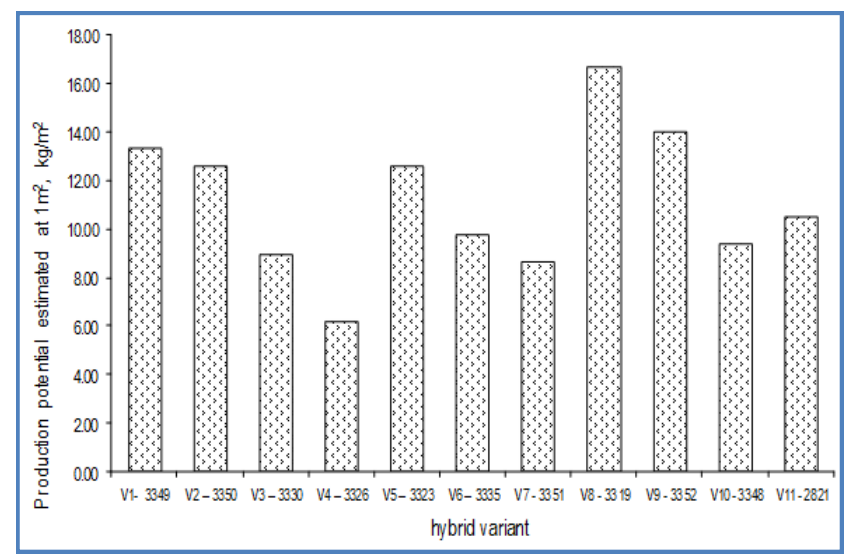

Fig. 4- Production potential estimated at one $\mathrm{m}^{2}$

In [Table-8] the characteristics of tomato fruits are presented to all hybrids analyzed. Thus index of form, relationship between the height and the diameter of the fruit, showed that the fruits have had generally spherical shape flattened on most variants except of variant 11 where the fruits were elongated, the index being 1.25.

In cross section was observed that the number of the seminal loggias was lower at variants 11 and 8 (2-3 loggias).

Immature fruits showed a uniform green color to the variants $1,2,3,5,6,8$ and 11 and only at the variants $4,7,9$ and 10 was noted the presence of dark green with collaret. At the physiological maturity the fruits have had deep red color except of variant 11 where the fruits were red-orange easily.

Table 8- The characteristics of tomato fruits to hybrids tested

\begin{tabular}{|c|c|c|c|c|c|c|c|c|}
\hline Variants & $\begin{array}{l}\text { Shape of the } \\
\text { fruit IF }\end{array}$ & $\begin{array}{c}\text { Number of semi- } \\
\text { nal loggias }\end{array}$ & Unripe fruit color & $\begin{array}{l}\text { Physiological maturity } \\
\text { of the fruit color }\end{array}$ & Fruit appearance & $\begin{array}{l}\text { Pericarp thick- } \\
\text { ness, } \mathrm{cm}\end{array}$ & $\begin{array}{l}\text { Size of the pes- } \\
\text { tle area, mm }\end{array}$ & Peak shape \\
\hline V1-3349 & 0.85 & $4-5$ & Uniform green & Red uniform & Smooth & 0.7 & $2-3 \mathrm{~mm}$ & Without peak \\
\hline V2-3350 & 0.79 & 4 & Green & Red uniform & $\begin{array}{l}\text { Fruit coated prone } \\
\text { to cracking easily }\end{array}$ & 0.8 & $4-5 \mathrm{~mm}$ & Without peak \\
\hline V3-3330 & 0.84 & 4 & Green & Red uniform & Smooth & 0.5 & $2-3 \mathrm{~mm}$ & Without peak \\
\hline V4-3326 & 0.75 & 3 & Green with collaret & Red uniform & slightly rippled & 0.6 & $1-2 \mathrm{~mm}$ & Without peak \\
\hline V5-3323 & 0.84 & $3-4$ & Green & Red uniform & easily coated & 0.7 & $2-3 \mathrm{~mm}$ & Without peak \\
\hline V6-3335 & 0.73 & $3-4$ & Green & Red uniform & easily coated & 0.7 & $4-5 \mathrm{~mm}$ & Without peak \\
\hline V7-3351 & 0.67 & 4 & Green with collaret & Red uniform & Smooth & 0.9 & $1-2 \mathrm{~mm}$ & Without peak \\
\hline V8-3319 & 0.85 & $2-3$ & Green & Red uniform & Smooth & 0.8 & $1-2 \mathrm{~mm}$ & Without peak \\
\hline V9-3351 & 0.82 & 4 & Green with yellow collaret & Red uniform & Smooth & 0.7 & $2-3 \mathrm{~mm}$ & Without peak \\
\hline V10-3348 & 0.85 & 4 & Green with collaret & Red uniform & Smooth & 0.7 & $2-3 \mathrm{~mm}$ & Without peak \\
\hline V11-2821 & 1.25 & 2 & Green & Red-orange & Smooth & 0.5 & absent & Without peak \\
\hline
\end{tabular}

Table 9- Fruits firmness and dry substance content on 7-19-2011

\begin{tabular}{|c|c|c|c|c|}
\hline \multirow{3}{*}{ Variants } & $\begin{array}{l}\text { At the temper- } \\
\text { ature of } 9^{\circ} \mathrm{C}\end{array}$ & $\begin{array}{l}\text { At ambient } \\
\text { temperature }\end{array}$ & $\begin{array}{l}\text { At the temper- } \\
\text { ature of } 9^{\circ} \mathrm{C}\end{array}$ & $\begin{array}{c}\text { At ambient } \\
\text { temperature }\end{array}$ \\
\hline & \multicolumn{2}{|c|}{ Firmness } & \multicolumn{2}{|c|}{ Dry substance } \\
\hline & $\mathrm{kgf} / \mathrm{cm}^{2}$ & $\mathrm{kgf} / \mathrm{cm}^{2}$ & $\%$ & $\%$ \\
\hline V1 & 1.79 & 4.7 & 4.7 & 5.1 \\
\hline V2 & 1.96 & 5.4 & 5.4 & 5 \\
\hline V3 & 1.19 & 5.5 & 5.5 & 5 \\
\hline V4 & 2.07 & 5.4 & 5.4 & 4.6 \\
\hline V5 & 2.32 & 5.3 & 5.3 & 4.7 \\
\hline V6 & 1.74 & 4.6 & 4.6 & 4.6 \\
\hline V7 & 2.11 & 5.7 & 5.7 & 6 \\
\hline V8 & 1.59 & 5.2 & 5.2 & 4.9 \\
\hline V9 & 3.7 & 5.4 & 5.4 & 5.4 \\
\hline V10 & 1.9 & 5.3 & 5.3 & 4.6 \\
\hline V11 & 1.17 & 5.6 & 5.6 & 4.8 \\
\hline
\end{tabular}

The thickness of pericarp was small only to V11 meaning of $0.5 \mathrm{~cm}$.

Another characteristic was the size of pestle area that most of the times when this is large can be characterized as a defect because the fruit can crack this area. Most fruits showed a smooth appearance except variants $2.4,5$ and 6 , where appearance was slightly coated. All variants showed no peak fruits appearance being rounded.

Fruit firmness at harvest was between 4.6 and $5.7 \mathrm{~kg} / \mathrm{cm}^{2}$ to $6 \mathrm{~kg} /$ $\mathrm{cm}^{2} \mathrm{~V}$ to V7. In terms of $9^{\circ} \mathrm{C}$ temperature, storage for 14 days it was observed that fruit firmness was lowers [Table-9]. 


\section{Conclusion}

The analysis of assessment of those 11 hybrids from Israel in early spring climatic conditions of Romania led us to some interesting conclusions. Thus between the seeds those 11 hybrids the lowest germination rate have had hybrids V4-3326 and V8-3319. While most of hybrids were germinated in 4-5 days hybrid V4-3326 hybrid germinated after 9 days and V8-3319 after 11 days. In addition, they had the lowest germination percentage namely $92 \%$ for V4 and $87 \%$ for V8.

In terms of seedlings developing, has been an increase between $0.295 \mathrm{~cm} /$ day and $0.363 \mathrm{~cm} /$ day. The lowest rate of growth of seedlings had the variant V4 and the highest the variant V11.

At planting tomato seedling with the fewest leaves was hybrid noted V8 with an average of 4.33 leaves while the most for V1 with an average by 7 leaves/plant. In addition at planting seedlings of $1,2,9,10$ and 11 variants showed hypocotyls of purple color.

As it was found until, planting the variant V8 showed the worst performance followed by the variant 4 . Even in the solar, the lowest height has had a hybrid V8-3319.

Pursuing formation of inflorescences and then fruits is one of the most important issues for horticulturists. Thus, plants had a different number of inflorescences respective flowers. Ratio between the number of flowers and the fruit produced was also different. Thus, although hybrid $\mathrm{V} 1$ has had one of the largest numbers of flowers of which only $61.54 \%$ have produced fruit, being one of the weakest production hybrids. At the same time the hybrid that look the weakest growth during seedling production (v8) produced the highest percentage of fruit connected, namely $91.89 \%$.

In terms of fruits size the smallest fruits with an average of $52.24 \mathrm{~g} /$ fruit were produced by the hybrid V4-3326 and the highest with an average of $163.7 \mathrm{~g} /$ fruit were produced by the variant V9-3352.

Evaluating the production capacity per plant and the potential production per $1 \mathrm{~m}^{2}$ has found that the variant V4 has the lowest potential of $6.1571 \mathrm{~kg} / \mathrm{m}^{2}$. It is very interesting that the greatest potential productive it has the variant 8 (hybrid 3319) of $16.667 \mathrm{~kg} / \mathrm{m}^{2}$, the one that was seen from the start as the variant with the lowest capacity of germination and growth. This is extremely significant because this hybrid not only has a large production capacity but it is the earliest of all hybrids tested. Thus even from the first harvest gathered $54.4 \%$ of the total production at this hybrid.

As regards of fruits firmness in storage conditions for 2 weeks at $9^{\circ}$ $\mathrm{C}$ most resistant fruits proved those provided by the hybrid V73351.

These results lead to the suggestion of the experiments to improve germination capacity of the hybrid V8 and recommendations for early crops in solar, in climate conditions in Romania.

\section{Acknowledgements}

This paper is supported by a contract funded by Executive Unit for Financing Higher Education, the Research, Development and Innovation Grant PN-II-PT-PCCA-2011-3.2-135, CNCSIS-UEFISCSUPartnerships Program, Bucharest, Str. D.I. Mendeleev nr. 21-25, sector1, Romania.

\section{References}

[1] Bleekera P.M., Mirabellaa R., Diergaardeb P.J., VanDoornb A., Tissierc A., Kantd M.R., Prinsb M., de Vosb M., Haringa M.A., Schuurinka R.C. (2012) Proc. Natl. Acad. Sci. USA, 1-6.

[2] Draghici E.M. (2009) Producerea Semintelor si Materialului saditor la Specii Legumicole, Romania, 35-42.

[3] Ciofu R., Stan N., Popescu V., Chilom P., Apahidean S., Horgoş A., Berar V., Lauer K.L. and Atanasiu N. (2004) Tratat de legumicultură.

[4] Mayeaux M., Xu Z., King J.M., Prinyawiwatkul W. (2006) J. Food Sci., 71, C461-464.

[5] Berova M., Stoeva N., Zlatev Z., Ganeva D. (2008) Scientific Journal In Agriculture, 9(4), 723-732.

[6] Suchindra R., Sankaranarayanan R., Nainar P. (2012) Plant Archives, 12(1), 257-258.

[7] Ali W., Jilani M.S., Naeem N., Waseem K., Khan J., Ahmad M.J., Ghazanfarullah (2012) Sarhad J. Agric., 28(2), 207-212.

[8] Pandey Y., Pun A., Upadhyuy K. (2006) Nepal Agric. Res. J., 7, 11-15

[9] Suchindra R., Sankaranarayanan R., Nainar P. (2012) Plant Archives, 12(1), 245-247.

[10]Ahmad F., Khan O., Sarwar S., Hussain A., Ahmad S. (2007) Sarhad J. Agric., 23(3), 581-585.

[11]Kacjan Maršić N., Osvald J., Jakše M. (2005) Acta Agriculturae Slovenica, 85(2), 321-328.

[12]Drăghici E.M., Hoza G. (2009) Bulletin of Agricultural Sciences and Veterinary Medicine Cluj-Napoca, 66(1).

[13]Drăghici E.M., Dobrin E. (2011) Lucrări Stiinţifice USAMV Bucureşti, Seria B, LV, 89-93.

[14]Lushi I., Balaj N., Haxhinasto L., Zhitia O. (2009) Acta. Hort., 830, 163-168.

[15]Mejia L., Teni R.E., Vidavski F., Czosnek H., Lapidot M., Nakhla M.K., Maxwell D.P. (2005) Acta. Hort., 695, 251-256.

[16]Commission Directive (2008) Official Journal of the European Union. L 219/55-L 219/57. 